\title{
TEISĖS AKTO GALIOJIMO SUSTABDYMO INSTITUTAS LIETUVOS KONSTITUCINĖS JUSTICIJOS MODELYJE
}

Santrauka. Lietuvos Respublikos Konstitucijos 106 straipsnio penktojoje dalyje nustatyta, kad Respublikos Prezidento teikimas Konstituciniam Teismui ar Seimo nutarimas ištirti, ar aktas sutinka su Konstitucija, sustabdo šio akto galiojimą. Teisès akto galiojimo sustabdymo institutas detaliau reglamentuojamas Konstitucinio Teismo įstatymo 26 straipsnyje. Vis dèlto pastarujų metų Lietuvos Respublikos Konstitucinio Teismo jurisprudencija šio instituto taikymo klausimu teisininku bendruomenėje ir viešojoje erdvèje susilaukia ịvairių vertinimų. Šiame straipsnyje siekiama atskleisti Konstitucijos ir Konstitucinio Teismo įstatymo nuostatų, reglamentuojančiu teisès akto galiojimo sustabdymo institutą, taip pat šio instituto sampratos formuojamos Konstitucinio Teismo jurisprudencijoje probleminius aspektus, bei pateikti siūlymus, kaip būtų galima tobulinti ši institutą reglamentuojantị teisinị reguliavimą.

Pagrindiniai žodžiai: Konstitucija, Konstitucinis Teismas, teisės akto galiojimo sustabdymas.

\section{THE SUSPENSION OF THE VALIDITY OF A LEGAL ACT IN THE CONSTITUTIONAL JUSTICE MODEL OF LITHUANIA}

\begin{abstract}
Paragraph five of Article 106 of the Constitution of the Republic of Lithuania provides that, the presentation by the President of the Republic for the Constitutional Court or the resolution of the Seimas asking for an investigation into the conformity of an act with the Constitution shall suspend the validity of the act. The suspension of validity of legal act is regulated in more detail in Article 26 of the Law on the Constitutional Court. However, in recent years the practice of application of this institute and the concept of this institute formed in the jurisprudence of the Constitutional Court are receiving a very wide discussion in the Lithuanian legal community and in the public in general. This article seeks to reveal the problematic aspects of the provisions of the Constitution and the Law on the Constitutional Court regulating the institute of suspension of the validity of legal act, as well as the problematic aspects of the conception of this institute formed in the jurisprudence of the Constitutional Court and to make proposals on how to improve the legal framework governing this institute.
\end{abstract}

Keywords: Constitution, Constitutional Court, suspension of the validity of legal act.

"Vilniaus universiteto Teisès fakulteto, Viešosios teisès katedros asistentė, socialinių mokslų daktarè,dovile.puraite@gmail.com. 


\title{
INSTYTUCJA ZAWIESZENIA OBOWIĄZYWANIA AKTU PRAWNEGO W LITEWSKIM MODELU SĄDOWNICTWA KONSTYTUCYJNEGO
}

\begin{abstract}
Streszczenie. Artykuł 106 zd. 5 Konstytucji Republiki Litewskiej stanowi, że zwrócenie się przez Prezydenta lub Sejm do Sądu Konstytucyjnego o zbadanie zgodności aktu z Konstytucją powoduje zawieszenie obowiązywania takiego aktu. Szczegółowa regulacja zawieszenia obowiązywania takiego aktu zawarta jest w art. 26 ustawy o Sądzie Konstytucyjnym. Niemniej jednak w ciągu ostatnich lat orzecznictwo Sądu Konstytucyjnego w kwestii stosowania tej instytucji stało się przedmiotem bardzo szerokiej dyskusji w litewskim środowisku prawniczym. Opracowanie ma na celu ukazanie problematycznych aspektów dotyczących z jednej strony przepisów Konstytucji i ustawy o Sądzie Konstytucyjnym, które regulują instytucję zawieszenia obowiązywania aktu prawnego, a z drugiej - problematycznych aspektów związanych z rozumieniem tej instytucji, jaka jest kształtowana w orzecznictwie Sądu Konstytucyjnego. Na zakończenie autorka dąży do przedstawienia propozycji ulepszenia regulacji prawnej instytucji zawieszenia obowiązywania aktu prawnego.
\end{abstract}

Słowa kluczowe: Konstytucja, Sąd Konstytucyjny, zawieszenie obowiązywania aktu prawnego.

\section{IVADAS}

Konstitucijos (Lietuvos Respublikos Konstitucija 1992) 106 straipsnio penktojoje dalyje nustatyta, kad Respublikos Prezidento teikimas Konstituciniam Teismui ar Seimo nutarimas ištirti, ar aktas sutinka su Konstitucija, sustabdo šio akto galiojimą. Šis konstitucinis institutas detaliau reglamentuojamas Konstitucinio Teismo įstatymo (Lietuvos Respublikos Konstitucinio Teismo istatymas 1993) (toliau - KTİ) 26 straipsnyje „Respublikos Prezidento, Seimo ir Vyriausybės aktų galiojimo sustabdymas”. Tačiau pastarųų metų Lietuvos Respublikos Konstitucinio Teismo jurisprudencija šio instituto taikymo klausimu teisininkų bendruomeneje ir viešojoje erdveje susilaukia itin plataus aptarimo. Diskutuojama ịvairiais klausimais. Ką konkrečiai reiškia šis institutas? Kokius teisinius padarinius sukelia teisès akto galiojimo sustabdymas? Pagaliau, kodèl būtent tik Respublikos Prezidento ir Seimo kreipimaisi dèl teisès akto konstitucingumo stabdo teisès akto galiojimą? Kodèl tokių padarinių nesukelia kitų subjektų kreipimaisi?

Kai kurie šios problematikos elementai analizuoti V. Sinkevičiaus (Sinkevičius 2017, 50-66), taip pat šio straipsnio autorès darbuose (Pūraitė-Andrikienė 2017, 338-341; Pūraitè-Andrikienè 2020, 83-84), tačiau dažniausiai apie šį institutą tik trumpai užsimenama, kai analizuojama bendra Konstitucinio Teismo kompetencija. Taigi išsamių mokslo darbų, kuriuose būtų ieškoma atsakymo ì paminètus ir kitus probleminius teisès akto galiojimo sustabdymo instituto paskirties Lietuvos konstitucinès justicijos modelyje klausimus, stokojama. 
Taigi šio darbo objektas - Konstitucijos ir KT! nuostatos, reglamentuojančios teisės aktų galiojimo sustabdymą, taip pat šio instituto sampratą atskleidžiančios Konstitucinio Teismo aktų nuostatos. Straipsnio tikslas - atskleisti Konstitucijoje ir KTİ nuostatų, reglamentuojančių teisès akto galiojimo sustabdymo institutą, taip pat šio instituto sampratos formuojamos Konstitucinio Teismo jurisprudencijoje probleminius aspektus, bei pateikti siūlymus, kaip būtų galima tobulinti šị institutą reglamentuojantị teisinị reguliavimą. Siekiant ịgyvendinti išsikeltą tikslą darbe keliami ir sprendžiami šie uždaviniai: 1) atskleisti šio instituto paskirtị ir raidą Lietuvos konstitucinès justicijos modelyje; 2) išanalizuoti probleminius šio instituto taikymo aspektus Konstitucinio Teismo jurisprudencijoje; 3) pateikti siūlymus kaip būtų galima tobulinti teisès akto galiojimo sustabdymo institutą reglamentuojantị teisinị reguliavimą.

Tyrimas atliktas derinant skirtingus, leidžiančius atskleisti tiek teorinę, tiek praktinę analizuojamų klausimų problematiką, metodus - dokumentų analizę, loginę, sisteminę, kritinę, lyginamąją, teleologinę, lingvistinę analizę.

\section{TEISĖS AKTO GALIOJIMO SUSTABDYMAS: TEISINIO SAUGUMO PRINCIPAS VS. APSAUGA NUO NEPATAISOMŲ ŽALINGŲ PADARINIŲ}

Minèta, kad pagal Konstitucijos 106 str. 5 d., Respublikos Prezidento teikimas Konstituciniam Teismui ar Seimo nutarimas ištirti, ar aktas sutinka su Konstitucija, sustabdo šio akto galiojimą. KTI 26 str. „Respublikos Prezidento, Seimo ir Vyriausybės aktų galiojimo sustabdymas" šią nuostatą sukonkretina. Tai, kad šis institutas kelia neaiškumų atspindi ir šio KTI straipsnio pakeitimų gausa.

Šiame KTI straipsnyje nustatytas teisinis reguliavimas buvo koreguojamas net 5 kartus (daugiausiai iš visų KTI straipsnių ${ }^{1}$ ): 1) originalioje šio straipsnio redakcijoje buvo įtvirtinta galimybè sustabdyti tik Respublikos Prezidento ir Vyriausybès aktų galiojimą, 1996 m. priimtu KTİ pakeitimo ịstatymu 26 str. 1 d.; nustatyta galimybė sustabdyti taip pat ir Seimo priimtų teisès aktų galiojimą; 2) 1998 m. pakeitimo įstatymu KTI 26 str. 1 d. nustatyta, kad ne vẻliau kaip per 3 dienas turi būti atliktas išankstinis medžiagos tyrimas ir tvarkomajame posėdyje išspręstas klausimas, ar priimti prašymą nagrinèti Konstituciniame Teisme ne tik tais atvejais, kai jis gauna Seimo nutarimą ištirti įstatymo ar kito Seimo akto atitiktị Konstitucijai, bet ir tais atvejais, kai jis gauna Seimo nutarimą ištirti Prezidento ar Vyriausybės akto atitiktį Konstitucijai ir įstatymams; 3) trečią kartą KTI 26 str. nustatyta Respublikos Prezidento, Seimo ir Vyriausybės aktų galiojimo sustabdymo tvarka tikslinta $2003 \mathrm{~m}$. priimtu pakeitimo ịstatymu, šiame straipsnyje nustatyta, kad ne véliau kaip per 3 dienas turi būti atliktas išankstinis medžiagos tyrimas ir tvarkomajame posėdyje išspręstas klausimas, ar priimti

${ }^{1}$ Plačiau apie KTỊ pakeitimus žr. Pūraitè-Andrikienè 2017, 128-138. 
prašymą nagrinèti Konstituciniame Teisme ne tik tais atvejais, kai Konstitucinis Teismas gauna Respublikos Prezidento teikimą ištirti, ar Vyriausybès aktas atitinka Konstituciją, bet ir tais atvejais, kai jis gauna Prezidento teikimą ištirti, ar Vyriausybės aktas atitinka ịstatymus, KTİ 26 str. 2 d. taip pat nustatyta pareiga skelbti apie teisès aktų galiojimo sustabdymą Konstitucinio Teismo interneto tinklalapyje; 4) $2012 \mathrm{~m}$. pakeitimo ịstatymu šis straipsnis keistas siekiant suderinti KTİ nuostatas su Lietuvos Respublikos teisėkūros pagrindų ịstatymo nuostatomis, t.y. Teisèkūros pagrindų ịstatyme numačius, kad nuo $2013 \mathrm{~m}$. kovo $1 \mathrm{~d}$. teisès aktai ir informacija skelbiama ne leidinyje „Valstybės žinios”, šio leidinio priede „Informaciniai pranešimai”, o Teisès aktų registre, internete, KT!̨ ịtvirtinta, kad Konstitucinio Teismo pirmininko pranešimai dèl ginčijamo akto galiojimo sustabdymo ir dèl sustabdyto akto galiojimo atnaujinimo skelbiami Teisès aktų registre; 5) $2015 \mathrm{~m}$. priimtu pakeitimo įstatymu 26 str. 1 d. padaryti tam tikri redakcinio pobūdžio pataisymai.

Taigi šis institutas patyre ir pakankamai rimtų legislatyvinių korekcijų (1996 m., 1998 m., 2003 m. pakeitimais šis institutas buvo koreguojamas tikslinant jo objektų, t.y. teisès aktų, kuriems jis gali būti taikomas, sąrašą), tačiau vèlesnès šio instituto korekcijos KTI̦ buvo daugiau redakcinio pobūdžio.

Dabar galiojančios redakcijos KTI 26 str. nustatyta, kad, gavus atitinkamą Respublikos Prezidento teikimą ar Seimo nutarimą, ne vèliau kaip per tris dienas turi būti nuspręsta, ar priimti prašymą nagrinèti; jei prašymas priimamas nagrinèti, Konstitucinio Teismo pirmininkas tuoj pat apie tai paskelbia Konstitucinio Teismo interneto svetaineje ir Teisès aktų registro tvarkytojui pateikia pranešimą, kuriame nurodo tikslų ginčijamo akto pavadinimą, jo prièmimo datą ir tai, kad pagal Konstitucijos 106 str. minèto akto galiojimas sustabdomas nuo šio pranešimo oficialaus paskelbimo Teisės aktų registre dienos iki Konstitucinio Teismo nutarimo dèl šios bylos paskelbimo.

Pirmaisiais veiklos metais Konstitucinis Teismas savo jurisprudencijoje išaiškino kai kuriuos svarbius teisès akto galiojimo sustabdymo instituto bruožus $^{2}$. Konstitucinis Teismas 1997 m. lapkričio 13 d. sprendime pažymėjo, kad apskritai įstatymų galiojimo sustabdymas yra nebūdingas įstatymų leidybai ir gali sukelti visuomeneje nestabilumo, nepasitikejjimo teisine sistema būseną, sudaryti prielaidas atsirasti teisès spragoms, tad taikomas tik retais, išimtiniais, Konstitucijoje numatytais atvejais. Šiame sprendime taip pat konstatuota, kad Konstitucijoje numatyti tik du atvejai, kai teisès akto (taigi ir įstatymo) galiojimas gali būti sustabdytas: pirma, pagal Konstitucijos 106 straipsnio ketvirtąją dalị „Respublikos Prezidento teikimas Konstituciniam Teismui ar Seimo nutarimas ištirti, ar aktas sutinka su Konstitucija, sustabdo šio akto galiojimą"; antra, Konstitucijos 145 straipsnyje nustatyta, kad esant ypatingoms sąlygoms - įvedus

${ }^{2}$ Vèlesnè Konstitucinio Teismo jurisprudencija šio instituto taikymo klausimu aptariama kitame šio straipsnio skyriuje. 
karo ar nepaprastąją padètị - gali būti laikinai apribojamos teisès ir laisvès, nurodytos Konstitucijos 22, 24, 25, 32, 35 ir 36 straipsniuose. Tai galètų būti padaroma sustabdant atitinkamų įstatymų normų galiojimą. Konstitucinis Teismas pabrèžè, kad kitų ịstatymo galiojimo sustabdymo atvejų Konstitucija nenumato.

Taigi pagal Konstitucinio Teismo oficialiąją doktriną, šis institutas gali būti taikomas itin retais (išimtiniais) atvejais, kurių baigtinis sąrašas yra numatytas Konstitucijoje. Svarbu pažymėti, kad šiame straipsnyje analizuojamas tik pirmasis iš minètame Konstitucinio Teismo sprendime nurodytų atvejų, kai teisès akto galiojimas gali būti sustabdytas. Paminètina, kad kai kurios Europos valstybès (pvz., Bulgarija, Čekija, Kipras, Latvija, Liuksemburgas, Portugalija, Prancūzija, Rumunija) siekdamos užtikrinti teisinio saugumo principą, savo teisès sistemoje tokio ar panašaus instituto nėra įtvirtinusios (European Commission For Democracy Through Law 2010, 38). Atsižvelgiant ị tai, kad konstitucinès justicijos institucijos sprendimas sustabdyti teisès akto galiojimą turi erga omnes pasekmes, teisinio saugumo principo užtikrinimo kontekste atsargi Konstitucinio Teismo pozicija šio instituto, kaip išimtinės priemonès, taikymo klausimu suprantama ir pateisinama. Konstitucinio Teismo jurisprudencijoje ne kartą konstatuota, kad iš konstitucinio teisinès valstybès principo kylantys teisètų lūkesčių apsaugos, teisinio tikrumo, teisinio saugumo principai suponuoja valstybès pareigą užtikrinti teisinio reguliavimo tikrumą ir stabilumą, apsaugoti asmenų teises, gerbti teisètus interesus ir teisètus lūkesčius (inter alia Konstitucinio Teismo 2014 m. balandžio 14 d. nutarimas).

Antra vertus, aptariamas teisès akto galiojimo sustabdymo institutas yra priskiriamas prie konstitucinių teismų taikomų laikinųjų apsaugos priemonių, kuri yra reikalinga siekiant užtikrinti, kad pareiškejjas ar visuomenė nepatirtų neatitaisomos žalos. Europos komisijos "Demokratija per teisę" (Venecijos komisijos) nuomone, konstituciniai teismai turi turèti igaliojimus sustabdyti ginčijamo teisès akto galiojimą, jei toliau taikant teisès aktą grèstų didelè žala ar pažeidimai, kurių nebūtų galima ištaisyti vẻliau konstatuojant, kad teisės aktas yra antikonstitucinis (European Commission For Democracy Through Law 2010, 38). Mokslinèje literatūroje atkreipiamas dèmesys, kad konstitucinio teismo sprendimas sustabdyti teisès akto (ypač įstatymo) galiojimą turi itin plačias erga omnes pasekmes, nors teisès akto konstitucingumas dar nėra ịvertintas. Todèl tvirtinama, kad tik ypač didelè ir neatitaisoma žala pareiškejjui ar visuomenei gali būti pagrindas teisès akto (ypač ịstatymo) galiojimo sustabdymui (Dürr 2016, 283).

Taigi apibendrinant galima konstatuoti, kad mokslo doktrinoje ir Venecijos komisijos studijose šio instituto paskirtis apibūdinama siekiu užskirsti kelią tam tikroms neigiamoms pasekmėms, kurios grèstų ir toliau taikant ginčijamą teisès aktą. 


\section{PROBLEMINIAI TEISĖS AKTO GALIOJIMO SUSTABDYMO INSTITUTO TAIKYMO ASPEKTAI LIETUVOS RESPUBLIKOS KONSTITUCINIO TEISMO JURISPRUDENCIJOJE}

Gricžtant prie padarinių, kurių siekiama išvengti teisès akto galiojimo sustabdymo instituto panaudojimu, visų pirma aptartinas Lietuvos teisininkų bendruomenèje įvairių vertinimų susilaukęs Konstitucinio Teismo 2020 m. gegužès 28 d. sprendimas ,Dèl atsisakymo pagal pareiškèjos Lietuvos Aukščiausiojo Teismo teisèjos Sigitos Rudėnaitės prašymą aiškinti Konstitucinio Teismo 2020 m. gegužès 13 d. sprendimą ir Konstitucinio Teismo pirmininko 2020 m. gegužès 13 d. pranešimą".

Pareiškèja prašè

išaiškinti, kokius konkrečius padarinius teisèjos Sigitos Rudėnaitės, kaip atleistosios Lietuvos Aukščiausiojo Teismo Civilinių bylų skyriaus pirmininkès, statuso ir teisių bei pareigų atžvilgiu sukèlè Konstitucinio Teismo $2020 \mathrm{~m}$. gegužès 13 d. sprendimas, kuriuo priimtas LR Seimo 2020 m. gegužès 7 d. nutarime išdèstytas prašymas ištirti LR Seimo ir LR Prezidento aktų nuostatų atitiktị LR Konstitucijai ir sustabdytas šių teisès aktų galiojimas, ir šio sprendimo pagrindu paskelbtas Lietuvos Respublikos Konstitucinio Teismo pirmininko 2020 m. gegužès 13 d. pranešimas.

Aptariamu sprendimu atsisakyta priimti S. Rudènaitės prašymą, nes Konstitucinio Teismo ir jo pirmininko aktai, kuriuos prašyta išaiškinti, nėra baigiamieji aktai, kuriais išnagrinèjama byla, taip pat dėl to, kad prašymą pateikè asmuo, neturintis teisès kreiptis ị Konstitucinị Teismą su prašymu oficialiai išaiškinti Konstitucinio Teismo nutarimą, išvadą ar sprendimą.

Prieš išsamesnị šio sprendimo nuostatų aptarimą, visų pirmą tikslinga trumpai pristatyti aplinkybes, kuriomis S. Rudènaitẻ buvo atleista iš pareigų. Teisiniu požiūriu kuriozinè situacija dèl S. Rudènaitès atleidimo iš pareigų susiklostė kai Seimas $2020 \mathrm{~m}$. balandžio $21 \mathrm{~d}$. atskirai balsavo už du atitinkamo Seimo nutarimo klausimus: pirmuoju klausimu jis nusprendè atleisti S. Rudènaitę iš Lietuvos Aukščiausiojo Teismo Civilinių bylų skyriaus pirmininkès pareigų (slapto balsavimo rezultatai: 68 Seimo nariai - už atleidimą, 34 - prieš, susilaikè 17), o po to balsavo už antrą nutarimo straipsnị ,paskirti Lietuvos Aukščiausiojo Teismo teisėją S. Rudènaitę Lietuvos Aukščiausiojo Teismo pirmininke”, kurio prièmimui pritrūko balsų (slapto balsavimo rezultatai: 52 Seimo nariai balsavo už paskyrimą, 46 - prieš, o 23 susilaikè). Taigi Seimas ne tik nepaskyrè šios Aukščiausiojo Teismo teisèjos ị šio Teismo pirmininkès pareigas, bet ir atleido ją iš užimamų šio teismo Civilinių bylų skyriaus pirmininkès pareigų, o kartu ir iš laikinosios šio teismo pirmininkès pareigu, kurias ji laikinai èjo pagal Teismų ìstatymą.

Ši situacija susilaukè itin aštrios kritikos teisininkų bendruomenèje ir plačiojoje visuomenèje. Reaguodamas ị tai, 2020 m. gegužès 7 d. Seimas, prièmè nutarimą kreiptis ị Konstitucinị Teismą su prašymu ištirti savo $2020 \mathrm{~m}$. balandžio 
21 d. nutarimo atitiktį Konstitucijai. Minèta, kad šis Seimo in corpore kreipimasis i Konstitucinị Teismą sustabdè ginčijamo Seimo nutarimo galiojimą.

Kaip minèta, mokslo darbuose, Venecijos komisijos studijose teisès akto galiojimo sustabdymo instituto paskirtis apibūdinama siekiu užskirsti kelią tam tikroms neigiamoms pasekmèms, kurios grèstų ir toliau taikant ginčijamą teisės aktą. Lietuvos teisininkų bendruomenèje taip pat dominavo požiūris, kad minèto Seimo nutarimo galiojimo sustabdymas sustabdys ir ginčijamo akto sukeltas teisines pasekmes (šiuo atveju - atleisti teisejją iš minètų pareigų). Pvz., V. Nekrošius tvirtino, jog „būtų visiškai teisinga, kad iki Konstitucinis Teismas galutinai išspręs situaciją, būtų atkurta iki ginčijamo akto buvusi status quo" (Delfi 2020). E. Šileikio nuomonè, „laikinai išnyko kliūtis minètai teisejjai toliau eiti anksčiau eitas teismo skyriaus pirmininkès pareigas (ir jų pagrindu laikinos LAT pirmininkès pareigas)" (Šileikis 2020). V. Vaičaičio nuomone,

šio konstitucinio instituto pritaikymas aptariamam atvejui reiškia, kad Seimo nutarimas kreiptis ị Konstitucinį Teismą dèl 2020 m. balandžio 21 d. Seimo nutarimo (kuriuo teisèja S. Rudènaitè buvo atleista iš Aukščiausiojo Teismo Civilinių bylų skyriaus pirmininkès pareigų) konstitucingumo, atkūrè iki pastarojo Seimo nutarimo egzistavusią teisinę situaciją, t. y. teisèja S. Rudènaitè $2020 \mathrm{~m}$. balandžio 21 dieną vèl pradèjo eiti Civilinių bylų skyriaus pirmininkès ir laikinosios Aukščiausiojo Teismo pirmininkès pareigas (Vaičaitis 2020).

Vis dèlto V. Sinkevičius dèl šios situacijos ir apskritai dèl aptariamo instituto paskirties pateike kitokią nuomonę. Jo tvirtinimu,

tai, kad Konstitucinis Teismas prièmè nagrinèti Seimo prašymą, sustabdo teisès akto galiojimą, bet neatstato teisinių pasekmių, kurios kilo iš to teisès”, „situacija yra įšaldoma, situacija lieka tokia, kokia tam momentui yra, o ji tokia, kad ji atleista. Tol, kol teismas neišsprende kitaip, laikoma, kad viskas, kas įvyko pagal tą teisès aktą iki įšaldymo, yra teisèta (Delfi 2020).

Grịžtant prie Konstitucinio Teismo 2020 m. gegužès 28 d. sprendimo, pažymètina, kad Konstitucinis Teismas laikèsi pastarosios pozicijos. Sprendime konstatuota, kad Konstitucijos 106 straipsnio 5 dalyje numatytas teisès akto galiojimo sustabdymas tais atvejais, kai dèl šio akto atitikties Konstitucijai i Konstitucini Teismą kreipiasi Respublikos Prezidentas arba Seimas savo nutarimu, savaime nepaneigia iš Konstitucijos 107 straipsnio 1 dalies kylančios ginčijamo teisės akto konstitucingumo ir jo taikymo padarinių teisėtumo prezumpcijos. Kartu Konstitucinis Teismas konstatavo, kad Seimo 2020 m. balandžio 21 d. nutarimas „Dèl Lietuvos Aukščiausiojo Teismo teisejos Sigitos Rudènaitès atleidimo iš šio teismo Civilinių bylų skyriaus pirmininko pareigų" jau sukèlè teisinius padarinius - Lietuvos Aukščiausiojo Teismo teisèja S. Rudènaitė yra atleista iš šio teismo Civilinių bylų skyriaus pirmininko pareigų.

Sprendime taip pat pažymèta, kad Konstitucinis Teismas ne kartą yra konstatavęs, kad Konstitucinio Teismo sprendimas priimti pareiškejjo Seimo prašymą ir atitinkamo teisès akto galiojimo sustabdymas prièmus prašymą nepanaikina ir nepakeičia ịvykusių teisinių padarinių. 
Apibendrindamas Konstitucinis Teismas konstatavo, kad jo $2020 \mathrm{~m}$. gegužès $13 \mathrm{~d}$. sprendimu prièmus pareiškejjo Seimo prašymą ištirti, ar inter alia Seimo 2020 m. balandžio 21 d. nutarimas neprieštarauja Konstitucijai ir Teismų istatymui, šio nutarimo galiojimo sustabdymas nereiškia, kad panaikinami ar pakeičiami įvykę teisiniai padariniai - Lietuvos Aukščiausiojo Teismo teisejos S. Rudènaitès atleidimas iš šio teismo Civilinių bylų skyriaus pirmininko pareigų, t.y. Seimo $2020 \mathrm{~m}$. balandžio $21 \mathrm{~d}$. nutarimo galiojimo sustabdymas negali būti aiškinamas kaip suteikiantis teisėjai S. Rudènaitei teisę eiti Lietuvos Aukščiausiojo Teismo Civilinių bylų skyriaus pirmininko pareigas, kol Konstitucinis Teismas neišnagrinėjo konstitucinès justicijos bylos pagal pareiškẻjo Seimo prašymą ir nèra ìsigaliojęs šioje byloje priimtas Konstitucinio Teismo nutarimas dèl inter alia Seimo 2020 m. balandžio 21 d. nutarimo atitikties Konstitucijai ir (arba) Teismų įstatymui.

Toks Konstitucinio Teismo išaiškinimas susilauke kritikos teisininkų bendruomenejje. E. Šileikis aptardamas tokią Konstitucinio Teismo poziciją pabrèžè, kad „sukūrus ši naują precedentą ateityje galètų kilti gerokai sudètingesnių problemų dèl vieno ar kito akivaizdžiai abejotino Seimo individualaus akto galiojimo sustabdymo padariniu ir ankstesnès tame akte negatyviai nurodyto asmens teisinès padèties atsikūrimo" (Šileikis 2020). V. Vaičaitis vertindamas tokị Konstitucinio Teismo teisès aktų galiojimo instituto paskirties išaiškinimą apskritai suabejojo šio instituto prasmingumu tvirtindamas, kad: ,jei sakytume, kad Konstitucijos žodžiai sustabdo šio akto galiojimą" reiškia tik kažkokị formalų teisinį akto suspendavimą, bet galètų palikti galioti šio ginčijamo akto sukeltas pasekmes teisiniams santykiams ir žmogaus teisèms, sunku būtų suprasti, kam apskritai Konstitucija numato šį „teisès akto galiojimo sustabdymo institutą" (Vaičaitis 2020).

Šiame kontekste paminètina, kad Vilniaus apygardos teismas $2020 \mathrm{~m}$. birželio 26 d. nutartimi tenkino ieškovès S. Rudènaitès prašymą dèl laikinųjų apsaugos priemonių taikymo ir grąžino S. Rudènaitę ị Lietuvos Aukščiausiojo Teismo Civilinių bylų skyriaus pirmininkès pareigas, iki bus priimtas teismo procesinis sprendimas dẻl ginčo esmès. Teismas pažymejjo, kad Konstitucinio Teismo $2020 \mathrm{~m}$. gegužès 28 d. sprendime pateikti išaiškinimai, susiję su Seimo nutarimo galiojimu ir jo laikinu sustabdymu, nekliudo ginčą nagrinėjančiam bendrosios kompetencijos teismui taikyti ieškovès šioje byloje prašomą laikinąją apsaugos priemonę. Šioje nutartyje pažymèta, kad nagrinèjamu atveju prašymas taikyti laikinąsias apsaugos priemones yra siejamas su teisinių santykių laikinu sureguliavimu, asmenų teisių apsaugos ir ginčo teisinių santykių normalaus funkcionavimo užtikrinimu, kol nèra priimtas ir įsiteisejęs teismo sprendimas. Teismas taip pat konstatavo, kad tokiu būdu būtų išvengta šiuo atveju tikètinų teismų sistemos nepriklausomumo pažeidimų. Vilniaus apygardos teismo nuomone, susiklosčiusios faktinès situacijos laikinai nesureguliavus, būtų sutrikdyta Lietuvos Aukščiausiojo Teismo darbo organizavimo tvarka bei yra tikimybė, kad kiltų neproporcinga žala, susijusi su Lietuvos valstybės turtiniais interesais. 
Iš tiesų toks Konstitucinio Teismo ${ }^{3}$ išaiškinimas, atribojantis teisès akto galiojimo sustabdymo instituto pritaikymą nuo ginčijamo teisinio reguliavimo sukeliamų padarinių, gali kelti pagrịstu abejonių dè šio instituto prasmingumo. Ypač atsižvelgiant ị tai, kad, kaip minèta, mokslinejje literatūroje pabrèžiama, kad šio instituto paskirtis ir yra užskirsti kelią, asmens ar visuomenès patiriamai žalai, t.y. tam tikriems neigiamiems padariniams, kol tikrinamas teisès akto konstitucingumas. Nors straipsnio autore iš dalies pritaria Konstitucinio Teismo pozicijai dèl to, kad teisès akto galiojimo sustabdymas nepanaikina ir nepakeičia įvykusių teisinių padarinių. Tačiau abejoja, ar tikslinga sutapatinti dvi skirtingas situacijas: padarinių panaikinimą/pakeitimą ir laikiną padarinių sustabdymą kol bus išnagrinètas teisès akto konstitucingumo klausimas.

Tačiau galbūt Lietuvos konstitucinès justicijos modelyje teisès akto galiojimo sustabdymas atlieka kažkokią kitą funkciją? Teisès moksle buvo diskutuojama (Sinkevičius 2017; Pūraitė-Andrikienè 2017, 338-341) dèl to, ar galima teisès aktą, kurio galiojimas sustabdytas, pripažinti netekusiu galios arba keisti? Konstitucinio Teismo $2008 \mathrm{~m}$. sausio 8 d. sprendime, kuriuo priimtas nagrinèti Seimo prašymas ištirti Respublikos Prezidento dekreto nuostatų konstitucingumą, konstatuota, kad šio prašymo prièmimas sustabdo minèto Respublikos Prezidento dekreto atitinkamų nuostatų galiojimą, tačiau nepanaikina ir nepakeičia minètų jau įvykusių teisinių padarinių. Kaip matyti, šiame sprendime Konstitucinis Teismas taip pat atribojo teisès akto galiojimo sustabdymą nuo ginčijamo teisinio reguliavimo padarinių, tačiau Teismas įvardijo kitą šio instituto paskirtį - tol, kol nebus priimtas atitinkamas Konstitucinio Teismo nutarimas dèl šio Respublikos Prezidento dekreto nuostatų atitikties Konstitucijai (galimai - ir įstatymams) ir apie tai nebus oficialiai paskelbta, Respublikos Prezidentas tuo metu negali pakeisti, papildyti ar panaikinti sustabdyto teisinio reguliavimo (Konstitucinio Teismo $2008 \mathrm{~m}$. sausio $8 \mathrm{~d}$. sprendimas).

Tokio reikalavimo tikslas - neleisti institucijai, išleidusiai ginčijamą teisès aktą išvengti bylos nagrinėjimo Konstituciniame Teisme. Juk tyrimas konstitucinès justicijos byloje gali būti jau pasistūmèjęs, eikvojami Konstitucinio Teismo resursai ir kt.

Tačiau naujausioje savo jurisprudencijoje nuo šio aiškinimo Konstitucinis Teismas nukrypo. Konstituciniam Teismui gavus Respublikos Prezidentes 2016 m. kovo 18 d. prašymą ištirti Vyriausybès nutarimo „Dèl Lietuvos Respublikos Vyriausybės 1992 m. gegužès 12 d.” nutarimo Nr. 343 „Dèl Specialiụjų žemės ir miško naudojimo sąlygų patvirtinimo" pakeitimo atitiktị Konstitucijai ir

${ }^{3}$ Šiame kontekste reikètų pažymèti, kad Konstitucinis Teismas 2020 m. rugsėjo 2 d. nutarimu pripažino, kad teisės aktai, susiję su Lietuvos Aukščiausiojo Teismo Civilinių bylų skyriaus pirmininkès atleidimu iš pareigų, prieštarauja Konstitucijai ir Teismų ịstatymui. Nutarime konstatuota, kad nuo šio Konstitucinio Teismo nutarimo oficialaus paskelbimo (įsigaliojimo) dienos Aukščiausiojo Teismo teisèja S. Rudènaitè eina Aukščiausiojo Teismo Civilinių bylų skyriaus pirmininko pareigas. 
ịstatymams pagal prièmimo tvarką, šio teisès akto galiojimas buvo sustabdytas. Vis dèlto rengiant bylą Konstitucinio Teismo posėdžiui, nepaisant to, kad šio akto galiojimas buvo sustabdytas, Vyriausybè ši aktą pripažino netekusiu galios. Aptariamoje byloje suinteresuotam asmeniui panaikinus ginčijamą teisès aktą, Konstitucinis Teismas, pasirèmęs savo ankstesne pozicija dẻl negaliojančių aktų tyrimo, konstatavo, kad kadangi ginčijamas teisès aktas yra pašalintas iš teisès sistemos, jo atitikties Konstitucijai ir ịstatymams tyrimas pagal prièmimo tvarką būtų savitikslis, ir konstitucinès justicijos bylą šioje dalyje nutraukè (Konstitucinio Teismo 2016 m. liepos 8 d. nutarimas).

Tačiau V. Sinkevičiaus nuomone, Konstitucinio Teismo 2008 m. sausio 8 d. sprendimo nuostata - kol nebus priimtas Konstitucinio Teismo sprendimas dèl Respublikos Prezidento dekreto atitikties Konstitucijai, Respublikos Prezidentas tuo metu negali pakeisti, papildyti ar panaikinti sustabdyto teisinio reguliavimo - buvo susijusi tik su to meto konkrečia teisine situacija: Konstitucinis Teismas neleido Seimui atšaukti savo sprendimo laikyti įstatymą nepriimtu, o Respublikos Prezidentui neleido atšaukti savo dekreto dèl įstatymo grąžinimo Seimui pakartotinai svarstyti, nes Seimas jau apsvarstė dekretą ir, kaip minèta, nutarè laikyti įstatymą nepriimtu. Anot šio autoriaus, Konstitucinis Teismas laikosi požiūrio, kad minèta $2008 \mathrm{~m}$. sausio $8 \mathrm{~d}$. sprendimo nuostata nèra oficiali konstitucinè doktrina. Todèl Konstitucinio Teismo 2016 m. liepos 8 d. nutarime „Vijūnèlès dvaro" byloje nerasime nuorodos ì minètą Konstitucinio Teismo 2008 m. sausio 8 d. sprendimą ir ị cituotą sprendimo nuostatą (Sinkevičius 2017, 57-58).

V. Sinkevičius taip pat pabrėžia, kad Konstitucinis Teismas pripažino, jog Vyriausybė galèjo panaikinti savo nutarimą, kurio galiojimas buvo sustabdytas pagal Konstitucijos 106 straipsnio ketvirtąją dali (Respublikos Prezidento kreipimasis ị Konstitucinị Teismą dèl Vyriausybės nutarimo atitikties Konstitucijai sustabdo Vyriausybės nutarimo galiojimą), reiškia, kad Konstitucinis Teismas suformavo oficialią konstitucinę doktriną: Konstitucija nedraudžia teisèkūros subjektams panaikinti, pakeisti ar papildyti savo išleistų įstatymų ir kitų teisès aktų, kurių galiojimas sustabdytas pagal Konstitucijos 106 straipsnio ketvirtają dalị (Sinkevičius 2017, 59).

Šio straipsnio autorès nuomone, teisès akto galiojimo sustabdymas turètų apimti ir tai, kad to teisès akto negalima jokiu būdu modifikuoti, t. y. keisti ar naikinti. Visų pirma todèl, kad priešinga pozicija leidžia institucijai, išleidusiai ginčijamą teisès aktą išvengti bylos nagrinėjimo Konstituciniame Teisme. Antra, jeigu teisès aktą, kurio galiojimas sustabdytas, galima pripažinti netekusiu galios arba keisti tuomet apskritai neaišku, kokia šio Lietuvos konstitucinès justicijos modelyje įtvirtinto instituto prasmè.

Atkreiptinas dėmesys, kad tai, kad nėra aišku ką konkrečiai reiškia teisès akto galiojimo sustabdymas rodo ir kiti šio instituto taikymo atvejai. Pvz., Konstituciniam Teismui teko „suktis iš situacijos” gavus Seimo prašymą 
ištirti, ar Konstitucijos 125 str. pakeitimo ịstatymas pagal prièmimo tvarką neprieštarauja Konstitucijai. Konstituciniam Teismui 2013 m. lapkričio 13 d. sprendimu prièmus pareiškejjo - Seimo prašymą ištirti, ar Konstitucijos 125 str. pakeitimo įstatymas pagal prièmimo tvarką neprieštarauja Konstitucijai, pagal Konstitucijos 106 str. 4 d., buvo sustabdytas būtent 2006 m. priimto Konstitucijos 125 str. pakeitimo įstatymo galiojimas. Konstitucinis Teismas konstatavo, kad ginčijamo įstatymo galiojimo sustabdymas nereiškia, kad kartu įsigalioja Konstitucijos 125 straipsnio redakcija, galiojusi iki ginčijamo Konstitucijos 125 straipsnio pakeitimo ịstatymo ịsigaliojimo; tai taip pat nereiškia, kad suvaržomas iš Konstitucijos 67 straipsnio 2 punkto kylantis Seimo įgaliojimas ịstatymu reguliuoti Lietuvos banko veiklą ir šio straipsnio 11 punkte nustatytas igaliojimas skirti ir atleisti Lietuvos banko valdybos pirmininką.

Apibendrintai galima konstatuoti, kad Konstitucinis Teismas savo jurisprudencijoje atskleisdamas šio instituto turinị kol kas akcentavo tai, ko teisès akto galiojimo sustabdymas nereiškia ar neapima. Tačiau šio Teismo jurisprudencijoje dar nèra aiškiai atskleista kas ị šio instituto turinị ịeina. Manytina, kad didele dalimi aptartos teisès akto galiojimo instituto taikymo problemos yra nulemtos šį institutą reglamentuojančio teisinio reguliavimo.

\section{SIŪLYMAI DĖL LIETUVOS KONSTITUCINĖS JUSTICIJOS MODELYJE ITVIRTINTO TEISĖS AKTO GALIOJIMO SUSTABDYMO INSTITUTO KOREGAVIMO}

Aptartos teisès aktų galiojimo sustabdymo instituto taikymo problemos Konstitucinio Teismo jurisprudencijoje suteikia pagrindą samprotauti dèl ji reglamentuojančio teisinio reguliavimo pagrịstumo ir svarstyti apie jo tobulinimo galimybès.

Pirma, atkreiptinas dèmesys, kad Lietuvos konstitucinès justicijos modelyje Konstitucinis Teismas neturi diskrecijos teisès akto galiojimo sustabdymo instituto klausimu: gavus atitinkamą Respublikos Prezidento teikimą ar Seimo nutarimą, jei prašymas priimamas nagrinèti, Konstitucinio Teismo pirmininkas Teisès aktų registro tvarkytojui pateikia pranešimą, kuriame nurodo tikslų ginčijamo akto pavadinimą, jo prièmimo datą ir tai, kad pagal Konstitucijos 106 str. minèto akto galiojimas sustabdomas. Tuo tarpu Venecijos komisijos nuomone, teisę nuspręsti ar taikyti tokią priemonę turètų turèti patys konstituciniai teismai. Diskrecijos laisvè šiuo klausimu palikta, inter alia, Austrijos, Albanijos, Armėnijos, Belgijos, Bosnijos-Hercegovinos, Kroatijos, Gruzijos, Vokietijos, Lenkijos, Serbijos, Slovénijos, Ispanijos konstituciniams teismams (European Commission for Democracy Through Law 2010, 38).

Antra, diskutuotinas ir kitas šio instituto elementas, t.y. kodèl būtent tik Seimo ir Respublikos Prezidento kreipimaisi sukelia tokius teisinius padarinius - stabdo 
ginčijamo akto galiojimą? Kodèl tokių teisinių padarinių nesukelia 1/5 Seimo narių grupės, teismų ar Vyriausybės kreipimaisi ị Konstitucinị Teismą? O nuo 2019 m. ir Konstitucijos 106 straipsnio ketvirtojoje dalyje nurodytų asmenų prašymai? Juk Konstituciniam Teismui pripažinus, jog atitinkamoje konstitucinès justicijos byloje ginčijamas teisès aktas prieštarauja Konstitucijai ar kitam aukštesnès galios teisès aktui, tokio nutarimo teisiniai padariniai bus vienodi nepriklausomai nuo subjekto, inicijavusio teisès akto konstitucingumo patikrą. Galbūt ịtvirtindami tokią nuostatą Konstitucijos kūrejai siekè parodyti išskirtinę pagarbą Prezidentui ir Seimui kaip aukščiausioms valstybės institucijoms. Tokiu būdu taip pat tikriausiai tam tikra prasme siekta užtikrinti valdžiu padalijimo principą. Pvz., Seimas neturi jokių ịgaliojimų dalyvauti Vyriausybès ar Prezidento aktų teisėkūros procese, tačiau kreipdamasis ị Konstitucinị Teismą jis gali sustabdyti atitinkamo Vyriausybès ar Prezidento akto galiojimą. Tai galima vertinti kaip tam tikrą stabdžių ir atsvarų mechanizmo elementą (Puraitè-Andrikienė 2017, 338-339). Vis dèlto manytina, kad atsižvelgiant ị šio instituto prasmę ir paskirtị, tikrai ne subjektai, kurie kreipèsi dèl tam tikro akto konstitucingumo, turètų lemti teisès akto galiojimo sustabdymo poreikị. Todẻl šio instituto taikymas neturètų būti diferencijuojamas pagal subjektus, kurie kreipèsi dẻl teisès akto konstitucingumo.

Trečia, grịžtant prie padarinių, kurių siekiama išvengti teisès akto galiojimo sustabdymo instituto panaudojimu, siūlytina, kad kriterijus lemiantis teisès akto galiojimo sustabdymo poreikị turètų būti tam tikros neigiamos pasekmès, kurios grèstų ir toliau taikant atitinkamą teisès aktą. T. y. kaip minèta pirmojoje šio straipsnio dalyje tai turètų būti didelių nepataisomų pasekmių grèsmė pareiškẻjui ar visuomenei.

Kaip pavyzdi galima pateikti Slovakijos Konstitucijos 125 str. 2 d. nustatytą teisinį reguliavimą, pagal kurị Konstitucinis Teismas prièmęs prašymą ištirti teisès akto konstitucingumą gali sustabdyti ginčijamų teisès aktų, jų dalių arba kai kurių nuostatų galiojimą, jeigu tolesnis jų taikymas galètų pažeisti pagrindines teises ir laisves, jeigu yra didelè ekonominès žalos arba kitų didelių nepataisomų pasekmių grèsmè (Constitution of the Slovak Republic 1992). Atkreiptinas demesys, kad pagal šias Slovakijos Konstitucijos nuostatas Konstituciniam Teismui paliekama diskrecijos laisvè nuspręsti, ar stabdyti atitinkamo akto galiojimą, šio instituto panaudojimo poreikis nèra siejamas su subjektais padavusiais prašymą dẻl teisès akto konstitucingumo, kriterijus lemiantis teisès akto galiojimo poreiki yra tam tikros neigiamos pasekmès kurios grèstų ir toliau taikant atitinkamą teisès aktą. Manytina, kad toks teisinis reguliavimas yra racionalesnis nei įtvirtintas Lietuvos konstitucinès justicijos modelyje.

Taigi siūlytina Konstitucijoje ir KTI ịtvirtintą teisès akto galiojimo sustabdymo institutą modifikuoti atsižvelgiant ị tai, kad kriterijus, lemiantis teisès akto galiojimo sustabdymą, turètų būti tam tikros neigiamos pasekmès, kurios grèstų ir toliau taikant atitinkamą teisès aktą, bet ne subjektai kurie padavė prašymą dèl teisès akto konstitucingumo, taip pat paliekant Konstituciniam 
Teismui diskrecijos laisvę nuspręsti, kada šio instituto panaudojimas yra reikalingas. Toks reguliavimas labiau užtikrintų balansą tarp dviejų konkuruojančių vertybių: teisinio saugumo principo ir pareiškejjo bei visuomenės apsaugos nuo nepataisomos žalos.

\section{IŠVADOS}

1. Pagal Konstitucinio Teismo oficialiają konstitucinę doktriną, teisès akto galiojimo sustabdymo institutas gali būti taikomas itin retais (išimtiniais) atvejais, kurių baigtinis sąrašas yra numatytas Konstitucijoje. Teisinio saugumo principo užtikrinimo kontekste atsargi Konstitucinio Teismo pozicija šio instituto, kaip išimtinès priemonès, taikymo klausimu suprantama ir pateisinama. Antra vertus, mokslo doktrinoje ir Venecijos komisijos studijose teisès akto galiojimo sustabdymo institutas yra priskiriamas prie konstitucinių teismų taikomų laikinujų apsaugos priemonių, kurios paskirtis apibūdinama siekiu užskirsti kelią tam tikroms neigiamoms pasekmėms, kurios grèstų ir toliau taikant ginčijamą teisès aktą.

2. Konstitucinis Teismas savo jurisprudencijoje atskleisdamas teisès akto galiojimo sustabdymo instituto turini akcentuoja tai, ko šis institutas nereiškia ar neapima. Tačiau šio Teismo jurisprudencijoje dar nèra aiškiai atskleista kas i aptariamo instituto turinị ịeina. Aptartos teisès aktų galiojimo sustabdymo instituto taikymo problemos Konstitucinio Teismo jurisprudencijoje suteikia pagrindą diskutuoti dèl ji reglamentuojančio teisinio reguliavimo pagrịstumo ir svarstyti apie jo tobulinimo galimybès.

3. Konstitucijoje ir Konstitucinio Teismo įstatyme ịtvirtintą teisès akto galiojimo sustabdymo institutą siūlytina modifikuoti atsižvelgiant $i ̣$ tai, kad kriterijus, lemiantis teisès akto galiojimo sustabdymą, turètų būti tam tikros neigiamos pasekmės, kurios grèstų ir toliau taikant atitinkamą teisės aktą, bet ne subjektai kurie padavé prašymą dèl teisès akto konstitucingumo, taip pat paliekant Konstituciniam Teismui diskrecijos laisvę nuspręsti, kada šio instituto panaudojimas yra reikalingas. Toks reguliavimas labiau užtikrintų balansą tarp dviejų konkuruojančių vertybių: teisinio saugumo principo ir pareiškejjo bei visuomenès apsaugos nuo nepataisomos žalos.

\section{BIBLIOGRAFIJA}

\section{SPECIALIOJI LITERATŪRA}

Dürr, Schnutz, Rudolf. 2016. Improving Human Rights Protection on the National and the European Levels - Individual Access to Constitutional Courts and the Accession of the European Union to the European Convention on Human Rights. https:/www.academia.edu/36018234/D\%C3\%BCrr Schnutz_Rudolf_Improving_Human_Rights_Protection_on_the_National_and_the_European_ Levels_Individual_Access_to_Constitutional_Courts_and_the_Accession_of_the_European_ 
Union_to_the_European_Convention_on_Human_Rights_Homenaje_a_Jean_Claude_Colliard_ Tomo_II_Mexico_2016_pp_267_298?email_work_card=title [žiūrèta: 9.10.2020].

European Commission For Democracy Through Law. 2010. Draft study on individual access to constitutional justice. http://www.venice.coe.int/webforms/documents/CDLJU(2010)004-e.aspx [žiūrèta: 9.10.2020].

Pūraitè-Andrikienè, Dovilè. 2017. Konstitucinès justicijos procesas Lietuvoje: optimalaus modelio paieška. PhD diss.: Vilnius University.

Pūraitė-Andrikienè, Dovilè. 2020. "Teisès aktų konstitucingumo patikros objektai Lietuvos Respublikos Konstitucinio Teismo jurisprudencijoje". Teise 116: 72-91.

Sinkevičius, Vytautas. 2017. "Teisès akto galiojimo sustabdymas: Lietuvos atvejis". Jurisprudencija 24 (4): 50-66.

\section{KITI ŠALTINIAI}

Delfi. 2020. Rudènaitè papraše Konstitucinio Teismo išaiškinimo dèl grịžimo ị darba. https://www. delfi.lt/news/daily/lithuania/rudenaite-paprase-konstitucinio-teismo-isaiskinimo-del-grizimoi-darba.d?id=84320039 [žiūrèta: 9.10.2020].

Šileikis, Egidijus. 2020. Konstitucija ir absurdas: F. Kafkos „procesas“ LAT teisèjos Rudènaitès situacijoje. https://www.delfi.lt/news/ringas/lit/egidijus-sileikis-konstitucija-ir-absurdas-f-kafkosprocesas-lat-teisejos-rudenaites-situacijoje.d?id=84456465 [žiūrèta: 9.10.2020].

Vaičaitis, Vaidotas. 2020. Konstituciniai pamastymai apie teisinę situacija dèl Aukščiausiojo Teismo pirmininko pareigu. https://www.15min.lt/naujiena/aktualu/nuomones/vaidotas-a-vaicaitiskonstituciniai-pamastymai-apie-teisine-situacija-del-auksciausiojo-teismo-pirmininkopareigu-18-1334950?copied [žiūrèta: 9.10.2020].

\section{TEISĖS AKTAI}

Lietuvos Respublikos Konstitucija, Žin. 1992, Nr. 33-1014.

Constitution of the Slovak Republic. Prieiga per internetą: https://www.prezident.sk/uploadfiles/46422.pdf. [žiūrèta: 9.10.2020].

Lietuvos Respublikos Konstitucinio Teismo įstatymas, Lietuvos aidas, Nr. 24; Žin. 1993, Nr. 6-120.

\section{LIETUVOS RESPUBLIKOS KONSTITUCINIO TEISMO NUTARIMAI IR SPRENDIMAI}

Konstitucinis Teismas 1997 m. lapkričio 13 d. sprendimas, Žin. 1997, Nr. 104-2644.

Konstitucinio Teismo 2008 m. sausio 8 d. sprendimas, Žin. 2008, Nr. 5-173.

Konstitucinio Teismo 2013 m. lapkričio 13 d. sprendimas, Žin. 2013, nr. 118-5945.

Konstitucinio Teismo 2014 m. balandžio 14 d. nutarimas, TAR 2014-04-15, Nr. 4467.

Konstitucinio Teismo 2016 m. liepos 8 d. nutarimas, TAR 2016-07-08, nr. 19478.

Konstitucinio Teismo 2020 m. gegužès 28 d. sprendimas. Nr. KT98-S93/2020.

Konstitucinio Teismo 2020 m. rugsèjo 2 d. nutarimas, TAR 2020-09-03, Nr. 18611.

\section{BENDROSIOS KOMPETENCIJOS TEISMŲ SPRENDIMAI}

Vilniaus apygardos teismo $2020 \mathrm{~m}$. birželio 26 d. nutartis, civilinè byloje Nr. e2-3287-852/2020. 